\title{
Endothelin $_{B}$ receptor-mediated contraction in human pulmonary resistance arteries
}

\author{
Kirsty M. McCulloch, Cheryl C. Docherty, Ian Morecroft \& 'Margaret R. MacLean
}

Division of Neuroscience and Biomedical Systems, Institute of Biomedical and Life Sciences, University of Glasgow, Glasgow, G12 8QQ

1 Using wire myography, we have examined the endothelin (ET) receptor subtypes mediating vasoconstriction to ET peptides in human pulmonary resistance arteries $(150-200 \mu \mathrm{m}$, i.d.).

2 Cumulative concentration-response curves to ET-1, sarafotoxin 6c (SX6c) and ET-3 were constructed in the presence and absence of the selective antagonists FR $139317\left(\mathrm{ET}_{\mathrm{A}^{-}}\right.$-selective), BMS $182874\left(\mathrm{ET}_{\mathrm{A}^{-}}\right.$ selective) and $\mathrm{BQ}-788$ (ET $\mathrm{B}_{\mathrm{B}}$-selective).

3 All agonists induced concentration-dependent contractions. However, the response curves to ET-1 were biphasic in nature. The first component demonstrated a shallow slope up to $1 \mathrm{nM}$ ET-1. Above $1 \mathrm{nM}$ ET-1 the response curve was markedly steeper. Maximum responses to ET-3 and SX6c were the same as those to $1 \mathrm{nM} \mathrm{ET-1}$ and $30 \%$ of those to $0.1 \mu \mathrm{M}$ ET-1. The order of potency, taking $0.3 \mu \mathrm{M}$ as a maximum concentration was SX6c $>>$ ET-3 $>$ ET-1 $\left(p \mathrm{EC}_{50}\right.$ values of: $10.75 \pm 0.27,9.05 \pm 0.19$, $8.32 \pm 0.08$ respectively). Taking $1 \mathrm{nM}$ ET- 1 as a maximum, the $\mathrm{EC}_{50}$ for ET-1 was $10.08 \pm 0.13$ and therefore ET-1 was equipotent to ET-3 and SX6c over the first component of the response curve.

4 Responses to ET-1 up to $1 \mathrm{nM}$ were resistant to the effects of the $\mathrm{ET}_{\mathrm{A}}$ receptor antagonists, FR 139317 and BMS 182874 but were inhibited by the $\mathrm{ET}_{\mathrm{B}}$ receptor antagonist, BQ-788. Conversely, responses to ET-1 over $1 \mathrm{nM}$ were inhibited by the $\mathrm{ET}_{\mathrm{A}}$ receptor antagonists, FR 139317 and BMS 182874 but unaffected by the $\mathrm{ET}_{\mathrm{B}}$ receptor antagonist, BQ-788.

5 The results suggest that at concentrations up to $1 \mathrm{nM}$, responses to ET-1 are mediated via the $\mathrm{ET}_{\mathrm{B}}$ receptor, whilst the responses to higher concentrations are mediated by $\mathrm{ET}_{\mathrm{A}}$ receptors.

Keywords: Endothelin receptors; human pulmonary arteries; vasoconstriction

\section{Introduction}

There is a growing evidence that endothelins (ETs) may be involved in the pathogenesis of human forms of pulmonary hypertension. Increased plasma endothelin-1 (ET-1) levels have been observed in patients with primary pulmonary hypertension (Stewart et al., 1991) and secondary pulmonary hypertension, due to chronic congestive heart failure and congenital heart defects (Cody et al., 1992; Yoshibayashi et al., 1991). Cody et al. (1992) also demonstrated that the plasma levels of ET-1 were well correlated with the degree of pulmonary hypertension observed and with the prognosis of the patient. High levels of ET-1 and ET-1 mRNA are present in the pulmonary vascular endothelial cells of patients with primary and secondary pulmonary hypertension (Giaid et al., 1993).

ET-1 may also be implicated in pulmonary hypertensive vascular remodelling due to its proliferative effect on pulmonary vascular smooth muscle cells and fibroblasts (Janakidevi et al., 1992; Hassoun et al., 1992; Peacock et al., 1992).

Targeting the actions of ET-1 in the pulmonary circulation using ET receptor antagonists has therefore been suggested as a possible therapeutic approach for the treatment of pulmonary hypertension. It is therefore of importance to characterize the receptors mediating the actions of ETs in the pulmonary vasculature.

We have previously demonstrated that the receptor subtype mediating ET-1-induced vasoconstriction in isolated pulmonary arteries of the rat varies, depending on the size and/or location of the artery under study (MacLean et al., 1994). The majority of studies in human vessels have been carried out on large diameter pulmonary arteries (average $3-5 \mathrm{~mm}$, i.d.) with the smallest diameter pulmonary artery used in functional studies being approximately $1 \mathrm{~mm}$, i.d. and these vessels demonstrate $\mathrm{ET}_{\mathrm{A}^{-} \text {-receptor-mediated vasoconstriction (Fukuroda }}$

\footnotetext{
${ }^{1}$ Author for correspondence.
}

et al., 1994a). It is thought that the pulmonary resistance arteries are functionally important in resistance changes observed in pulmonary hypertensive states and we wished therefore, to examine responses in small intrapulmonary resistance arteries from the human lung.

Preliminary data from these studies have been presented previously (McCulloch et al., 1994a, b; McCulloch \& MacLean, 1995).

\section{Methods}

Human pulmonary arteries $(150-200 \mu \mathrm{m}$, i.d.) were dissected from grossly normal sections of human lung removed from postoperative bronchial carcinoma tissue. Samples were refrigerated in fresh Krebs solution and were collected and studied no longer than $12 \mathrm{~h}$ postoperative. The vessels were mounted on a Mulvany Halpern small-vessel myograph (Mulvany \& Halpern, 1977). Tension was raised to give an equivalent transmural pressure of approximately $16 \mathrm{~mm} \mathrm{Hg}$. All vessels were bubbled with $16 \% \mathrm{O}_{2}, 5 \% \mathrm{CO}_{2}$, balance $\mathrm{N}_{2}$. This gave a final bath $\mathrm{O}_{2}$ concentration (measured with an oxygen electrode and blood gas analyser) of approximately $120 \mathrm{mmHg}$ and $\mathrm{CO}_{2}$ tensions of approximately $35 \mathrm{mmHg}$ to yield values equivalent to those found in pulmonary arteriolar blood. As these vessels have walls that are typically only $20 \mu \mathrm{m}$ thick, $\mathrm{O}_{2}$ diffusion problems are not encountered with active bubbling (Pittman \& Duling, 1973; Fishman, 1976). After 1 h equilibration period the vessels were contracted with $50 \mathrm{mM}$ $\mathrm{KCl}$. Following this, vessels were washed out three times with fresh Krebs solution and allowed to return to baseline tension. The vessels were then again pre-contracted with a second challenge $50 \mathrm{mM} \mathrm{KCl}$. Following washout and return to baseline tension the vessels were subjected to the following protocols: (A) 45 min equilibration period followed by a cumulative concentration-response curve (CCRC: $0.01 \mathrm{pM}$ to $0.3 \mu \mathrm{M})$ to either endothelin-1 (ET-1), endothelin-3 (ET-3) or 
sarafotoxin 6c (SX6c); (B) 45 min incubation with one concentration of the antagonist under study followed by CCRC to selected agonist.

\section{Drugs and solutions}

The composition of the Krebs-bicarbonate saline was as follows (in $\mathrm{mM}$ ): $\mathrm{NaCl} 118.4, \mathrm{NaHCO}_{3} 25, \mathrm{KCl} 4.7$, $\mathrm{KH}_{2} \mathrm{PO}_{4} 1.2, \mathrm{MgSO}_{4} 0.6, \mathrm{CaCl}_{2} 2.5$, glucose 11. The following drugs were used: endothelin-1 (Thistle, Glasgow, UK), Endothelin-3 (Peninsula Laboratories), sarafotoxin S6c (Sigma), BQ 788 ( $N$-cis-2,6-dimethylpiperidinocarbonyl L- $\gamma$-MeLeu-DTrp $\left(\mathrm{COOCH}_{3}\right)$-D-Nle; Peptide International), FR139317 ( $N$ CO-L-Leu-D-1-Me-Trp-D-3(2-Pyridyl) Ala-OH; Neosystems) and BMS 182874 (5-dimethylnamino)- $N$-(3,4-dimethyl-5-isoxzolyl)-1-naphthalenesulphonamide). Stock solutions of sarafotoxin S6c were prepared in $0.1 \%$ acetic acid and those to BQ 788 in $0.1 \%$ DMSO. All other drugs and dilutions were prepared in distilled $\mathrm{H}_{2} \mathrm{O}$.

\section{Data analysis}

Results are expressed graphically as percentage of the reference contraction to the second application of $50 \mathrm{mM} \mathrm{KCl}$ or as a percentage of the maximum response to ET-1. The $p \mathrm{EC}_{50}$ values were calculated by computer interpolation from individual CCRCs. Statistical comparisons of the means of groups of data were made by Student's $t$ test for paired or unpaired data; $P<0.05$ was considered statistically significant. An estimated $\mathrm{p} K_{\mathrm{B}}$ value for $\mathrm{BQ}-788$ against ET-3 was calculated from the following equation: $\mathrm{p} K_{\mathrm{B}}=-\log ([\mathrm{B}] / \mathrm{DR}-1)$ where $\mathrm{B}$ represents the concentration of antagonist studied and DR is the dose-ratio produced by the antagonist. Due to the nature of antagonism displayed by BMS 182874 and BQ-788 vs. ET-1, it was not possible to calculate $\mathrm{p} K_{\mathrm{B}}$ values for these compounds. $\mathrm{n} / \mathrm{n}$ in text refers to the number of preparations in the number of lungs studied.

\section{Results}

The average internal diameter of pulmonary resistance arteries mounted on the myograph was $188 \pm 9 \mu \mathrm{m}$ at an average transmural pressure of $16.3 \pm 0.7 \mathrm{mmHg}(n=12) . \mathrm{KCl}(50 \mathrm{mM})$ induced contractions of $113 \pm 10 \mathrm{mg}$ wt. tension $(n=12 / 10)$. Figure 1 illustrates the tissue responses to ET-1, ET-3 and SX6c and data for $p \mathrm{EC}_{50}$ values are summarized in Table 1.

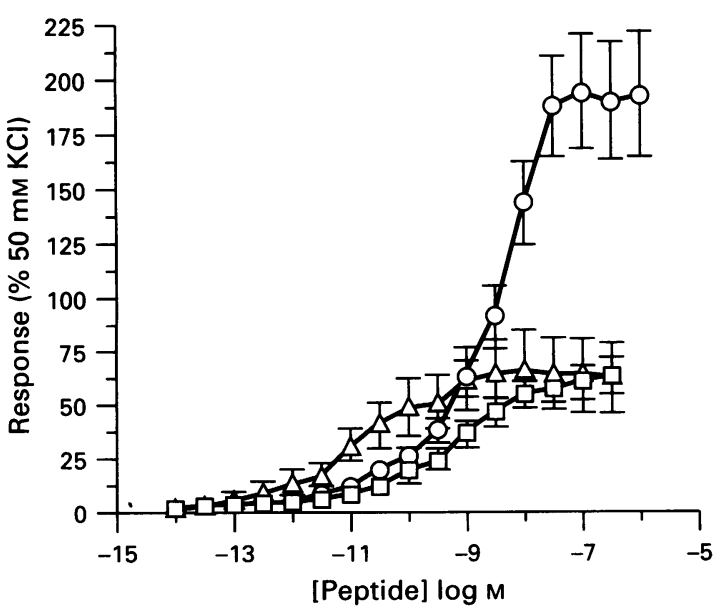

Figure 1 Cumulative concentration-response curves to endothelin-1 $(\bigcirc, n=12 / 10)$, endothelin-3 $(\square, n=10 / 10)$ and sarafotoxin S6c $(\triangle$, $n=10 / 6)$ in human pulmonary resistance arteries. Data are expressed as percentage reference contraction to $50 \mathrm{mM} \mathrm{KCl}$ in each vessel preparation. Each point represents the mean \pm s.e.mean.
The response to ET-1 comprised two components, one being a gradual slope up to $1 \mathrm{nM}$ and the second a steeper component at higher concentrations. Taking the CCRC to ET-1 as a whole, ET-3 was approximately five times more potent that ET-1 in this preparation (see Table 1) but produced a maximum contraction of approximately $30 \%$ of the contraction to $1 \mu \mathrm{M}$ ET-1 $(P<0.001)$. The selective $\mathrm{ET}_{\mathrm{B}}$ agonist, SX6c, was more potent than ET-1 and ET-3 in producing contractions in human pulmonary resistance arteries. These contractions were completely resistant to the actions of the $\mathrm{ET}_{\mathrm{A}}$ receptor antagonist, FR 139317 (Table 1). However, in a similar fashion to ET-3, SX6c produced a maximum contraction of approximately $30 \%$ of the contraction to $1 \mu \mathrm{M}$ ET- $1(P<0.001)$.

Incubation with antagonists at all concentrations studied had no effect on resting vascular tone. FR 139317 did not antagonize responses to ET-1 when present at $1 \mu \mathrm{M}$ (Figure 2; Table 1). However, when present at $10 \mu \mathrm{M}$, the antagonist caused a significant decrease in the response to ET-1 at $30 \mathrm{nM}$ and $0.1 \mu \mathrm{M}(P<0.001)$. BMS 182874 (a selective $\mathrm{ET}_{\mathrm{A}}$ receptor antagonist, $10 \mu \mathrm{M}$ ) did cause a significant decrease in the absolute contractile response to ET-1, but only in the range of $10 \mathrm{nM}$ to $0.1 \mu \mathrm{M}$ (Figure 3; Table 2). The first, shallow component of the ET-1 CCRC was unaffected by BMS 182874 .

BQ-788 (a selective $\mathrm{ET}_{\mathrm{B}}$ receptor antagonist) inhibited responses to ET-1 up to $1 \mathrm{nM}$ but not to higher con-

Table $1 p \mathrm{EC}_{50}$ values for endothelin-1(ET-1), endothelin-3 (ET-3) and sarafotoxin S6c (SX6c) in human pulmonary resistance arteries

\begin{tabular}{|c|c|c|}
\hline Agonist \pm antagonist & $p E C_{50}$ & $\mathrm{n} / \mathrm{n}$ \\
\hline ET-1 & $8.32 \pm 0.08$ & $12 / 10$ \\
\hline ET-3 & $9.05 \pm 0.19 * *$ & $10 / 10$ \\
\hline SX6c & $10.65 \pm 0.27 * * * \dagger \dagger \dagger$ & $10 / 6$ \\
\hline ET-1 + $1 \mu \mathrm{M}$ FR 139317 & $7.98 \pm 0.30$ & $8 / 6$ \\
\hline ET- $1+10 \mu \mathrm{M}$ FR 139317 & $8.80 \pm 0.21$ & $4 / 4$ \\
\hline ET $-1+10 \mu \mathrm{M}$ BMS 182874 & $8.20 \pm 0.26$ & $8 / 5$ \\
\hline $\mathrm{ET}-3+1 \mu \mathrm{M}$ BQ 788 & $7.43 \pm 0.13+\dagger \dagger$ & $7 / 5$ \\
\hline SX6c $+1 \mu \mathrm{M}$ FR 139317 & $10.55 \pm 0.25$ & $3 / 3$ \\
\hline
\end{tabular}

Data are expressed as mean \pm s.e.mean. $n / n$ : number of preparations from number of lungs. Statistical comparisons were made by Students unpaired $t$ test. ${ }^{* *} P<0.01$, *** $P<0.001$ vs. ET -1 . $\dagger+\dagger P<0.001$ vs. ET-3.

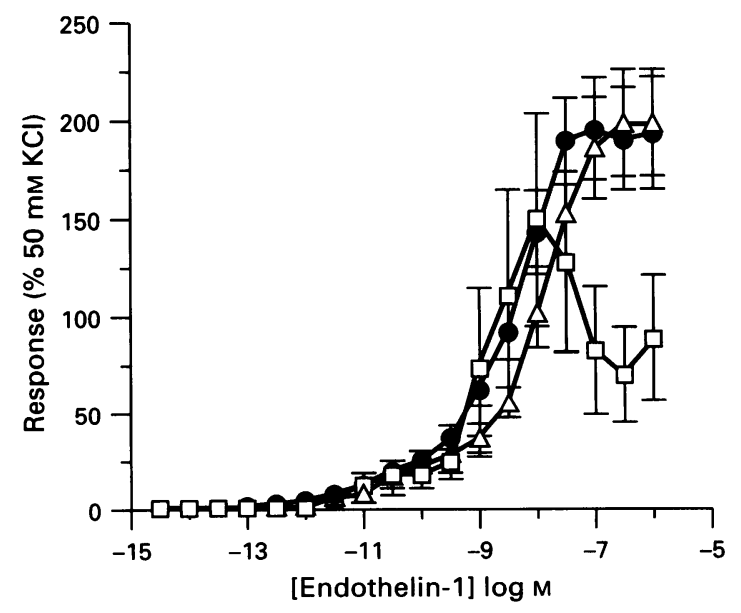

Figure 2 Endothelin-1 (ET-1) induced vasoconstriction in human pulmonary resistance arteries: effect of the $\mathrm{ET}_{\mathrm{A}}$ receptor antagonist, FR 139317. Cumulative concentration-response curves to ET-1 (O, $n=12 / 10)$, in the presence of $1 \mu \mathrm{M}$ FR $139317(\triangle, n=8 / 6)$ and in the presence of $10 \mu \mathrm{M}$ FR $139317(\square, n=4 / 4)$. Data are expressed as percentage reference contraction to $50 \mathrm{mM} \mathrm{KCl}$ in each vessel preparation. Each point represents the mean \pm s.e.mean. 




Figure 3 Endothelin-1 (ET-1)-induced vasoconstriction in human pulmonary resistance arteries: effect of the $\mathrm{ET}_{\mathrm{A}}$ receptor antagonist, BMS 182874. Cumulative concentration-response curves to ET-1 (O, $n=12 / 10)$ and in the presence of $10 \mu \mathrm{M}$ BMS $182874(O, n=8 / 5)$ Data are expressed as percentage reference contraction to $50 \mathrm{mM} \mathrm{KCl}$ in each vessel preparation. Each point represents the mean \pm s.e.mean.

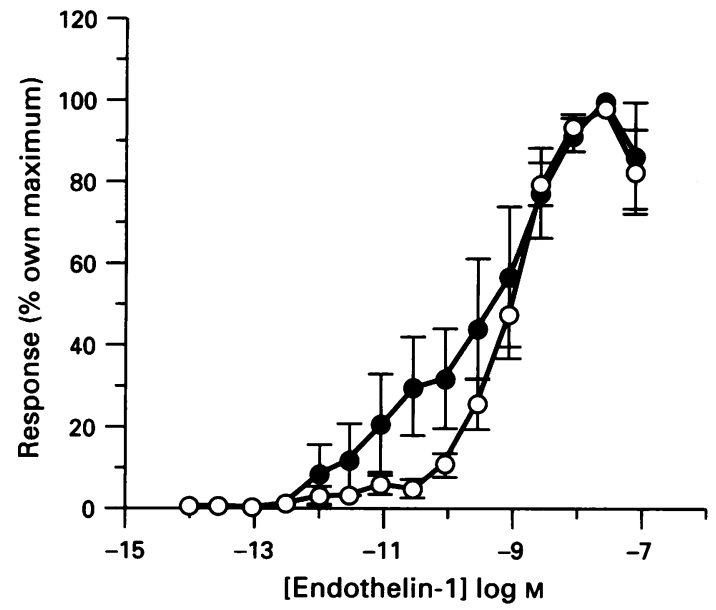

Figure 4 Endothelin-1 (ET-1) induced vasoconstriction in human pulmonary resistance arteries: effect of the $\mathrm{ET}_{\mathrm{B}}$ receptor antagonist, BQ-788. Cumulative concentration-response curves to ET-1 (O $n=4 / 4)$ and in the presence of $1 \mu \mathrm{M} B Q-788(O, n=4 / 4)$. Data are expressed as percentage own maximum contraction in each vessel preparation. Each point represents the mean \pm s.e.mean.

centrations (Figure 4). The maximum contraction to ET-1 was not altered in the presence of BQ-788 (control maximum contraction $=373 \pm 112 \%$ of $50 \mathrm{mM} \mathrm{KCl}$ response, and in the presence of $1 \mu \mathrm{M} \mathrm{BQ}-788=211 \pm 38 \%$ of $50 \mathrm{mM} \mathrm{KCl}$ response).

The presence of the antagonists further suggested that there were two components to the ET-1 CCRC, an $\mathrm{ET}_{\mathrm{B}}$-mediated component up to $1 \mathrm{nM}$ and an $\mathrm{ET}_{\mathrm{A}}$-mediated component at higher concentrations. Assuming that $1 \mathrm{nM}$ ET-1 gave the maximum response for the $\mathrm{ET}_{\mathrm{B}}$ component, the $\mathrm{EC}_{50}$ for this component was $10.08 \pm 0.13$. ET-1 was, therefore, equipotent to ET-3 and SX6c over the ' $\mathrm{ET}_{\mathrm{B}}$ ' component of the response curve.

BQ-788 $(1 \mu \mathrm{M})$ caused a rightward shift in the response curves to ET-3 in human pulmonary resistance arteries, without affecting the maximal contractile response to the peptide (Figure 5, Table I). The estimated $\mathrm{p} K_{\mathrm{B}}$ value for BQ788 against ET-3 was $7.72 \pm 0.22(n=7$ preparations from 5 lungs).

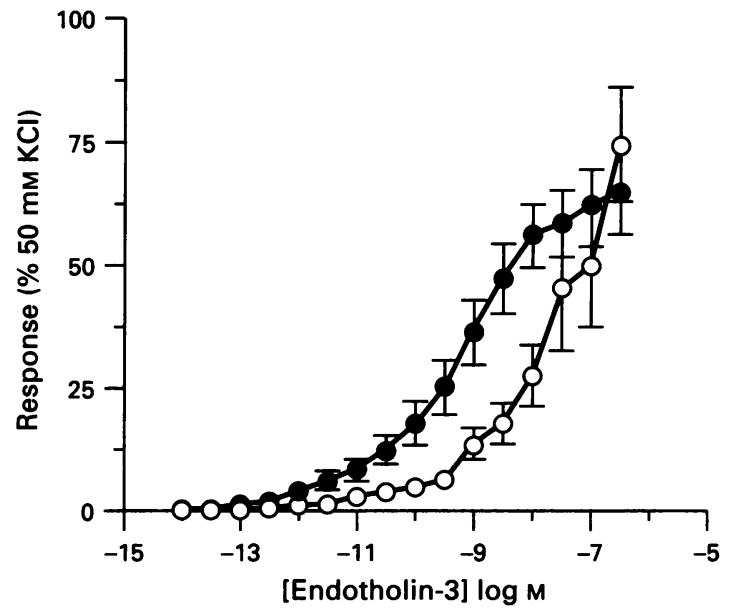

Figure 5 Endothelin-3 (ET-3)-induced vasoconstriction in human pulmonary resistance arteries: effect of the $\mathrm{ET}_{\mathbf{B}}$ receptor antagonist, BQ-788. Cumulative concentration-response curves to ET-3 (O, $n=10 / 10)$ and in the presence of $1 \mu \mathrm{M}$ BQ-788 $(O, n=7 / 5)$. Data are expressed as percentage reference contraction to $50 \mathrm{mM} \mathrm{KCl}$ in each vessel preparation. Each point represents the mean \pm s.e.mean.

\section{Discussion}

The response curve to ET-1 in human pulmonary resistance arteries is biphasic in nature, which suggests a heterogeneous population of ET-receptors. That ET-1-induced vasoconstriction is not mediated entirely by a typical $\mathrm{ET}_{\mathrm{A}}$-receptor in human pulmonary resistance arteries is suggested by its resistance to both of the $\mathrm{ET}_{\mathrm{A}}$-receptor antagonists studied. However, although the antagonists did not competitively shift the ET-1induced response, both FR $139317(10 \mu \mathrm{M})$ and BMS 182874 $(10 \mu \mathrm{M})$ significantly decreased the contractile response to high concentrations of ET-1. This would suggest that ET-1 may be acting at $\mathrm{ET}_{\mathrm{A}}$-receptors at high concentrations but at another receptor at low concentrations. A similar effect of the $\mathrm{ET}_{\mathrm{A}}$ receptor antagonist $\mathrm{BQ} 123$ has been observed in rabbit pulmonary artery where $\mathrm{ET}_{\mathrm{A}}$ and $\mathrm{ET}_{\mathrm{B}}$ receptors co-exist (La Douceur et al., 1993).

The selective $\mathrm{ET}_{\mathrm{B}}$ receptor agonist, $\mathrm{SX6c}$, was extremely potent at producing contractile responses, being over 200 fold more potent that ET-1. These contractions were resistant to the actions of the $\mathrm{ET}_{\mathrm{A}}$ receptor antagonist, FR 139317. The CCRC to SX6c followed a similar course to that of the first component of the CCRC to ET-1. The maximum contraction induced by SX6c was however only $30 \%$ of that caused by high concentrations of ET-1. Concentration-dependent contractile responses were also observed to ET-3. This peptide proved to be less potent than SX6c but 5 fold more potent than ET-1. In a similar fashion to SX6c, the maximum contraction induced by ET-3 was only some $30 \%$ of the maximum response induced by ET-1 in this preparation. The results also show that the CCRC to ET-3 follows a similar course to that of SX6c and the first component of the CCRC to ET-1. ET-1 and ET-3 would be expected to be equipotent at a classical $\mathrm{ET}_{\mathrm{B}}$ receptor subtype. However, in our results it can be seen that ET-3 is more potent that ET-1 when $0.3 \mu \mathrm{M}$ ET-1 is considered as the concentration causing maximum contraction. A receptor selective for ET-3 over ET-1 (denoted ET $_{\mathrm{C}}$ ) has been cloned in Xenopus laevis dermal melanophores (Karne et al., 1993). The relative potency of ET-3 over ET-1 in human pulmonary resistance arteries may suggest the presence of such an $\mathrm{ET}_{\mathrm{C}}$ receptor; however, a mammalian vascular counterpart of this receptor has yet to be identified.

The $\mathrm{ET}_{\mathrm{B}}$ receptor antagonist, $\mathrm{BQ}-788$, antagonized the contractile responses to concentrations of ET-1 up to $1 \mathrm{nM}$, suggesting that $E T-1$ is activating vascular $E_{B}$ receptors within this concentration-range. The inability of $\mathrm{BQ}-788$ to 
inhibit responses to ET-1 at concentrations greater than $1 \mathrm{nM}$ confirms the heterogeneity of the receptor population and combined with the ability of the selective $\mathrm{ET}_{\mathrm{A}}$ receptor antagonists to inhibit the responses to ET-1 above $1 \mathrm{nM}$, confirms that ET-1 activates $\mathrm{ET}_{\mathrm{A}}$ receptors at these high concentrations. The ability of $\mathrm{BQ}-788$ to antagonize responses to ET-3 confirms that ET-3 is mediating its response via ET $_{B}$ receptors in this preparation. Given that the results suggested an $\mathrm{ET}_{\mathrm{B}}$-receptor-mediated response to $\mathrm{ET}-1$ at concentrations up to $1 \mathrm{nM}$, we re-analyzed the sensitivity of the tissue to ET-1 over this component. The results show ET-1 was equipotent to both SX6c and ET-3, taking $1 \mathrm{nM}$ as a maximum concentration. This further supports the concept that $\mathrm{ET}_{\mathrm{B}}$-receptors are involved in the response to ET-1 up to $1 \mathrm{nM}$.

What are the physiological and pathophysiological concentrations of ET-1 to which the pulmonary vascular smooth muscle may be exposed? Under normal physiological conditions, ET-1 circulates within the plasma in the low picomolar range, with values often in the range of 0.5 to $5 \mathrm{pg} \mathrm{m}^{-1}$ of plasma (Miyauchi et al., 1991; Lam et al., 1991; Goerre et al., 1995; Ferri et al., 1995). There is considerable variation between groups as to the precise levels under normal conditions and this is probably due to sample populations, the assay techniques used for measurement and the site at which the samples are taken. However, all relevant studies are consistent in showing that the ET-1 levels are significantly increased in cases of pulmonary hypertension. The most dramatic increases in circulating ET-1 levels and ET-1 expression, appear to be associated with primary pulmonary hypertension (Stewart $e t$ al., 1991; Cacoub et al., 1993; Giaid et al., 1993; Nootens et al., 1995); although ET-1 levels are also significantly increased in pulmonary hypertension secondary to hypoxia (Stewart et al., 1991; Ferri et al., 1995), congenital heart defects (Yoshibayashi et al., 1991; Cacoub et al., 1993; Vincent et al., 1993), valvular heart disease (Stewart et al., 1991; Chang et al., 1993; Yamamoto et al., 1994; Zhu et al., 1994), chronic heart failure (Cody et al., 1992; Kiowski et al., 1995) and the adult respiratory distress syndrome (Langleben et al., 1993). Plasma ET-1 levels can be increased four fold in some of these studies. Although plasma levels of ET-1 give an indication of production, the actions of ET-1 may be more paracrine than endocrine in nature. It is thought that approximately $75 \%$ of ET-1 synthesized is secreted towards the vascular smooth muscle cells (Yoshimoto et al., 1991; Wagner et al., 1992), and given the small volumes of interstitial fluid, ET-1 concentrations may be significantly greater at the smooth muscle cell level compared to plasma levels. The results from our study would suggest that in vivo, ET-1 will cause contraction of the pulmonary resistance artery via the $\mathrm{ET}_{\mathrm{B}}$ receptor when present at concentrations below $1 \mathrm{nM}$. In the context of our in vitro studies, plasma ET-1 concentrations would be at the threshold level $\left(p \mathrm{EC}_{10}\right)$ required for contraction. Threshold concentrations of ET-1 have also been shown to facilitate contractions to other vasoactive compounds such as 5-hydroxytryptamine, angiotensin II and $\alpha_{2}$-adrenoceptor agonists (MacLean \& McGrath, 1990; Takeshita et al., 1991; Itoh et al., 1992). Indeed, it has been demonstrated in the forearm circulation of healthy human volunteers, under control conditions, that infusion of the $\mathrm{ET}_{\mathrm{A}}$ receptor antagonist, $\mathrm{BQ}-123$, mediates prolonged vasodilatation suggesting that ET-1 plays a role in the regulation of human vascular tone under normal physiological conditions (Haynes et al., 1995).

Interaction of ETs with the vascular endothelium in human pulmonary vessels is not well documented. Endothelial ET $_{\mathbf{B}}$ receptors have been shown to mediate pulmonary vasodilatation in rats (Eddahibi et al., 1991) and lambs (Wong et al., 1995), but whether this occurs in the human pulmonary circulation is not yet clear. It has also been reported that responses to ET-1 in human large diameter intrapulmonary arteries were not affected by cyclo-oxygenase inhibition (indomethacin) or NO synthase inhibition (L-NOARG), suggesting that local endogenous release of endothelium-derived relaxing factors may not be important in regulating the contractile responses to ET-1 in human pulmonary arteries in vitro (Pussard et al., 1995).

Unfortunately little is known about the actions of ETs in human lungs in vivo. From studies of isolated systemic vessels in vitro, it was generally thought that ET-1 contracted the majority of human arterial and venous preparations via the activation of $\mathrm{ET}_{\mathrm{A}}$ receptors (Davenport et al., 1994; Maguire et al., 1995). However, comparative studies in vivo would indicate that both $\mathrm{ET}_{\mathrm{A}}$ and $\mathrm{ET}_{\mathrm{B}}$ receptors mediate vasoconstriction in human resistance and capacitance vessels (Haynes et al., 1995). This discrepancy may be due to the size and or type of preparation studied, as there is growing evidence in vitro to suggest the presence of vascular $\mathrm{ET}_{\mathrm{B}}$ receptors in human arteries and veins (Seo et al., 1994; White et al., 1994; Dashwood et al., 1995). We therefore may expect to see contributions of both $\mathrm{ET}_{\mathrm{A}}$ and $\mathrm{ET}_{\mathrm{B}}$ receptors in mediating ET-1induced vasoconstriction in the human pulmonary circulation in vivo. $\mathrm{ET}_{\mathrm{A}}$ and $\mathrm{ET}_{\mathrm{B}}$ receptors mediate contraction in the human bronchi and in rabbit pulmonary artery. In these tissues, dual blockade of both receptors is required to antagonize responses to ET-1 fully (LaDouceur et al., 1993; Fukuroda et al., 1994b; 1996). Non-selective ET antagonists may, therefore, prove to be more effective antagonists in the human pulmonary arterial bed.

ET-induced responses and ET receptor subtypes in the pulmonary vasculature are altered in animal models of pulmonary hypertension (Eddahibi et al., 1991; Yorikane et al., 1993; Li et al., 1994; MacLean et al., 1995). Whether pulmonary vascular responses to ET-1 are altered in human pulmonary hypertension is not yet known and will be an important factor in determining the possible use of ET receptor antagonists as a therapy for pulmonary hypertension.

K.M. M. and C.C. D. hold Medical Research Council PhD studentships. This work was also supported by The Wellcome Trust and Tenovus (Scotland).

\section{References}

CACOUB, P., DORENT, R., MAISTRE, G., NATAF, P., CARAYON, A., PIETTE, C., GODEAU, P., CABROL, C. \& GANDJBAKHCH, I. (1993). Endothelin-1 in primary pulmonary hypertension and the Eisenmenger syndrome. Am. J. Cardiol., 71, 448-450.

CHANG, H., WU, G.J., WANH, S.M. \& HUMG, C.R. (1993). Plasma endothelin levels and surgically correctable pulmonary hypertension. Ann. Thor. Surg., 55, 450-458.

CODY, R.J., HAAS, G.J., BINKLEY, P.F., CAPERS, Q. \& KELLEY, R. (1992). Plasma endothelin correlates with the extent of pulmonary hypertension in patients with chronic congestive heart failure. Circulation, 85, 504-509.

DASHWOOD, M.R., TIMM, M. \& KASKI, J.C. (1995). Regional variations in $\mathbf{E T}_{\mathbf{A}} / \mathbf{E T}_{\mathbf{B}}$ binding sites in human coronary vasculature. J. Cardiovasc. Pharmacol., 26 (Suppl.3), S351S354.

DAVENPORT, A.P. \& MAGUIRE, J.J. (1994). Is endothelin-induced vasoconstriction mediated only by $\mathrm{ET}_{\mathbf{A}}$ receptors in humans. Trends Pharmacol. Sci. 15, 9-11.

EDDAHIBI, S., RAFFESTIN, B., BRAQUET, P., CHABRIER, P.E. \& ADNOT, S. (1991). Pulmonary vascular reactivity to endothelin-1 in normal and chronically pulmonary hypertensive rats. $J$. Cardiovasc. Pharmacol., 17 (Suppl.7), S358-S361. 
FERRI, C., BELLINI, C., DE ANGELIS, DE SIATI, L., PERRONE, A., PROPERZI, G. \& SANTUCCI, A. (1995). Circulating endothelin-1 concentrations in patients with chronic hypoxia. J. Clin. Pathol., 48, $519-524$

FISHMAN, A.P. (1976). Hypoxia on the pulmonary circulation. How and where it acts. Circ. Res., 38, 221-231.

FUKURODA, T., KOBAYASHI, M., OZAKI, S., YANO, M., MIYAUCHI, T., ONIZUKA, M., SUGISHITA, Y., GOTO, K. \& NISHIKIBE, M. (1994a). Endothelin receptor subtypes in human versus rabbit pulmonary arteries. J. Appl. Physiol., 76, 1976-1982.

FUKURODA, T., OZAKI, S., IHARA, M., ISHIKAWA, K., YANO, M., MIYAUCHI, T., ISHIKAWA, S., ONIZUKA, M., SUGISHITA, Y., GOTO, K. \& NISHIKIBE, M. (1996). Necessity of dual blockade of endothelin $\mathrm{ET}_{\mathrm{A}}$ and $\mathrm{ET}_{\mathrm{B}}$ receptor subtypes for antagonism of endothelin-1-induced contraction in human bronchi. $\mathrm{Br} . \mathrm{J}$. Pharmacol., 117, 995-999.

FUKURODA, T., OZAKI, S., IHARA, M., ISHIKAWA, K., YANO, M. \& NISHIKIBE, M. (1994b). Synergistic inhibition by BQ-123 and BQ-788 of endothelin-1-induced contractions of pulmonary artery. Br. J. Pharmacol., 113, 336-338.

GIAID, M., YANAGISAWA, M., LANGLEBEN, D., MICHEL, R.P., LEVY, R., SHENNIB, M., KIMURA, S., MASAKI, T., DUGUID, W. \& STEWART, D.J. (1993). Expression of endothelin in the lungs of patients with pulmonary hypertension. N. Engl. J. Med., 328, $1732-1739$.

GOERRE, S, WENK, M., BARTSCH, P., LUSCHER, T.F., NIROOMAND, F., HOHENHAUS, E., OELZ, O. \& REINHART, W.H. (1995). Endothelin-1 in pulmonary hypertension associated with highaltitude exposure. Circulation, 90, 359-364.

HASSOUN, P.M., THAPPA, V., LANDMAN, M.J. \& FANBURG, B.L. (1992). Endothelin-1: motogenic activity on pulmonary artery smooth muscle cells and release from hypoxic endothelial cells. Proc. Soc. Exp. Biol. Med., 199, 165-170.

HAYNES, W.G., STRACHAN, F.E. \& WEBB, D.J. (1995). Endothelin $\mathrm{ET}_{\mathrm{A}}$ and $\mathrm{ET}_{\mathrm{B}}$ receptors cause vasoconstriction of human resistance and capacitance vessels in vivo. Circulation, 92, 357363.

ITOH, H., HIRAOKA, N., HIGUCHI, H., ITO, M., KONISHI, T. \& NAKANO, T. (1992). Contractile actions of endothelin-1 in isolated helical strips from rat pulmonary artery: Potentiation of serotonin-induced contraction. J. Cardiovasc. Pharmacol., 20, $1-6$.

JANAKIDEVI, K., FISHER, M.A., DEL VECCHIO, P.J., TIRUPPATHI, C., FIGGE, J. \& MALIK, A.B. (1992). Endothelin-1 stimulates DNA synthesis and proliferation of pulmonary artery smooth muscle cells. Am. J. Physiol., 263, C1295-C1301.

KARNE, S., JAYAWIRCKREME, C.K. \& LERNER, M.R. (1993) Cloning and characterisation of an endothelin-3 specific receptor (ETC receptor) from Xenopus laevis dermal melanophores. J. Biol. Chem., 268, 19126-19133.

KIOWSKI, W., SÜTSCH, G., HUNZIKER, P., MÜLLER, P., KIM, J., OECHSLIN, E., SCHMITT, R., JONES, R. \& BERTEL, O. (1995) Evidence for endothelin-1-mediated vasoconstriction in severe chronic heart failure. Lancet, 346, 732-736.

LADOUCEUR, D.M., FLYNN, M.A., KEISER, J.A., REYNOLDS, E. \& HALEEN, S.J. (1993). ET $_{A}$ and $E_{B}$ receptors coexist on rabbit pulmonary artery vascular smooth muscle mediating contraction. Biochem. Biophys. Res. Commun., 196, 209-215.

LAM, H-C., TAKAHASHI, K., GHATEI, M.A., WARRENS, A.N., REES, A.J. \& BLOOM, S.R. (1991). Immunoreactive endothelin in human plasma, urine, milk and saliva. J. Cardiovasc. Pharmacol., 17 (Suppl. 7), S390-S393.

LANGLEBEN, D., DEMARCHIE, M, LAPORTA, D, SPANIER, A.H., SCHLESINGER, R.D. \& STEWART, D.J. (1993). Endothelin-1 in acute lung injury and the adult respiratory distress syndrome. Am. Rev. Respir. Dis., 148, 1646-1650.

LI, H., CHEN, S., CHEN, Y., MENG, Q.C., DURAND, J., OPARIL, S. \& ELTON, T.A. (1994). Enhanced endothelin-1 and endothelin receptor gene expression in chronic hypoxia. J. Appl. Physiol., $77,1451-1459$

MACLEAN, M.R., MCCULLOCH, K.M. \& BAIRD, M. (1994) Endothelin $\mathrm{ET}_{\mathrm{A}^{-}}$and $\mathrm{ET}_{\mathrm{B}^{-}}$receptor-mediated vasoconstriction in rat pulmonary arteries and arterioles. $J$. Cardiovasc. Pharmacol., 23, 838-845.

MACLEAN, M.R., MCCULLOCH, K.M. \& BAIRD, M. (1995). Effects of pulmonary hypertension on vasoconstrictor responses to endothelin-1 and sarafotoxin S6c and on inherent tone in rat pulmonary arteries. J. Cardiovasc. Pharmacol., 26, 822-830.
MACLEAN, M.R. \& MCGRATH, J.C. (1990). Effects of pre-contraction with endothelin-1 on $\alpha_{2}$-adrenoceptor and endothelium-dependent neuropeptide $\mathrm{Y}$ mediated contractions in the isolated vascular bed of the rat tail. Br. J. Pharmacol., 101, 205-211.

MAGUIRE, J.J. \& DAVENPORT, A.P. (1995). ET $_{\text {A-receptor-mediated }}$ constrictor responses to endothelin peptides in human blood vessels in vitro. Br. J. Pharmacol., 115, 191-197.

MCCULLOCH, K.M., BAIRD, M. \& MACLEAN, M.R. (1994a). Endothelin-1-induced contraction in human pulmonary arteries: mediated by $\mathrm{ET}_{\mathrm{A}}$-receptors in large arteries but non-ET $\mathrm{A} /$ non$\mathrm{ET}_{\mathrm{B}}$-receptors in resistance arteries. Thorax, 50, 452P.

MCCULLOCH, K.M., BAIRD, M. \& MACLEAN, M.R. (1994b). Heterogeneity and distribution of endothelin receptors involved in vasoconstrictor responses to endothelin-1 in human pulmonary arteries. Br. J. Pharmacol., 113, 161P.

MCCULLOCH, K.M. \& MACLEAN, M.R. (1995). Evidence for endothelin B $_{B}$ receptor-mediated contraction of human and rat pulmonary resistance arteries and the effect of pulmonary hypertension on endothelin receptor-mediated responses in the rat. J. Cardiovasc. Pharmacol., 26 (suppl 3), S169-S176.

MIYAUCHI, T., SUGISHITA, Y., YAMAGUCHI, I., AJISAKA, R., TOMIZAWA, T., ONIZUKI, M., MATSUDA, M., KONO, I., YANAGISAWA, M., GOTO, K., SUSUKI, N., MATSUMOTO, H. \& MASAKI, T. (1991). Plasma concentrations of endothelin-1 and endothelin-3 are altered differently in various pathophysiological conditions in humans. J. Cardiovasc. Pharmacol., 17 (Suppl. 7), S394-S397.

MULVANY, M.J. \& HALPERN, W. (1977). Contractile properties of small arterial resistance vessels in spontaneously hypertensive and normotensive rats. Circ. Res., 41, 19-26.

NOOTENS, M., KAUFMANN, E., RECTOR, T., TOHER, C., JUDD, D., FRANCIS, G.S. \& RICH, S. (1995). Neurohormonal activation in patients with right ventricular failure from pulmonary hypertension: relation to haemodynamic variables and endothelin levels. J. Am. Coll. Cardiol., 26, 1581-1585.

PEACOCK, A.J., DAWES, K.E., SHOCK, A., GRAY, A.J., REEVES, J.T. \& LAURENT, G.J. (1992). Endothelin-1 and endothelin-3 induce chemotaxis and replication of pulmonary fibroblasts. Am. J. Respir. Cell Mol. Biol., 7, 492-499.

PITTMAN, N.R. \& DULING, B.R. (1973). Oxygen sensitivity of vascular smooth muscle. Microvasc. Res., 6, 202-211.

PUSSARD, G., GASCARD, J.P., GORENNE, I., LABAT, C., NOREL, X., DULMET, E. \& BRINK, C. (1995). Endothelin-1 modulates cyclic GMP production and relaxation in human pulmonary vessels. $J$. Pharmacol. Exp. Ther., 274, 969-975.

SEO, B., OEMAR, B.S., SIEBERMANN, R., SEGESSER, L. \& LÜSCHER, T. (1994). Both $\mathrm{ET}_{\mathrm{A}}$ and $\mathrm{ET}_{\mathrm{B}}$ receptors mediate contraction to endothelin-1 in human blood vessels. Circulation, 89, 1203-1208.

STEWART, D.J., LEVY, R.D., CERNACEK, P. \& LANGLEBEN, D. (1991). Increased plasma Endothelin-1 in pulmonary hypertension: marker or mediator of disease. Ann. Intern. Med., 114, 464469.

TAKESHITA, H., NISHIKIBE, M., YANO, M. \& IKEMOTO, F. (1991). Coronary vascular response to endothelin in isolated perfused hearts of spontaneously hypertensive rats. Clin. Exp. Pharmacol. Physiol., 18, 661-669.

VINCENT, J.A., ROSS, R.D., KASSAB, J., HSU, J.M., PINSKY, W.W. (1993). Relation of elevated plasma endothelin in congeinital heart disease to increased pulmonary blood flow. Am. J. Cardiol., 71, 1204-1207.

WAGNER, O.F., CHRIST, G. \& WOJTA, J. (1992). Polar secretion of endothelin-1 by cultured endothelial cells. J. Biol. Chem., 267, $16066-16068$.

WHITE, D.G., GARRATT, H., MUNDIN, J.W., SUMNER, M.J., VALLANCE, P.J. \& WATTS, I.S. (1994). Human saphenous vein contains both endothelin $\mathrm{ET}_{\mathrm{A}}$ and $\mathrm{ET}_{\mathrm{B}}$ receptors. Eur. $J$. Pharmacol., 257, 307-310.

WONG, J., VANDERFORD, P.A., WINTERS, J, SOIFER, S.J. \& FINEMAN, J.R. (1995). Endothelin-B receptor agonists produce pulmonary vasodilation in intact newborn lambs with pulmonary hypertension. J. Cardiovasc. Pharmacol., 25, 207-215.

YAMAMOTO, K., IKEDA, U., MITO, H., FUJIKAWA, H., SEKIGUCHI, H. \& SHIMADA, K. (1994). Endothelin production in pulmonary circulation of patients of mitral stenosis. Circulation, 89, 20932098. 
YORIKANE, R., MIYAUCHI, T., SAKAI, S., SAKURAI, T., YAMAGUCHI, I., SUGISHITA, Y. \& GOTO, K. (1993). Altered expression of $\mathrm{ET}_{\mathrm{B}}$-receptor mRNA in the lung of rats with pulmonary hypertension. J. Cardiovasc. Pharmacol., 22, (Suppl. 8), S336S338.

YOSHIBAYASHI, M., NISHIOKA, K., NAKAO, K., SAITO, Y., MATSUMURA M., UEDA, T., TEMMA, S., SHIRAKAMI, G., IMURA, H. \& MIKAWA, H. (1991). Plasma endothelin concentrations in patients with pulmonary hypertension associated with congenital heart defects. Circulation, 48, 2280-2285.
YOSHIMOTO, S., ISHIZAKI, Y., SASAKI, T. \& MUROTA, S.I. (1991). Effect of carbon dioxide and oxygen on endothelin production by cultured porcine cerebral endothelial cells. Stroke, 22, 378-383. ZHU, Z.G., WANG, M.S., JIANG, Z.B., JIANG, Z., XU, S.X., REN, C.Y.\& SHI, M.X. (1994). The dynamic change of plasma endothelin-1 during the perioperative period in patients with rheumatic valvular disease and secondary pulmonary hypertension. J. Thor. Cardiovasc. Surg., 108, 960-968.

(Received July 22, 1996 Revised August 6, 1996 Accepted August 9, 1996) 